\title{
"ACADEMIC ADEQUACY OF THE ENGLISH PRE-SERVICE TEACHERSOF ILOCOS SUR POLYTECHNIC STATE COLLEGE”
}

\author{
Jocelyn Leonardo Absolor ${ }^{1}$ \\ College of Teacher Education, Ilocos Sur Polytechnic State College, 0777325512 Sta.Maria,Ilocos Sur,Philippines \\ jocelynlabsolor@gmail,com
}

\begin{abstract}
:
It is a requirement for pre-service teachers to be fully equipped academically and pedagogically beacuse they greatly impact the learning experiences of the students. This study assessed the academic adequacy of the pre-service English teachers of Ilocos Sur Polytechnic State College.It also determined thestudent and the school related profile of the respondents and were correlated to their academic adequacy.This investigation employed a descriptive method of research which involved the 21 BSED English major students. To gauge the students' academic adequacy,a 250 item teacher made test was utilized.The data were analyzed using mean and percentage, frequency count,Pearsonproduct moment of correlation, chi-square and spearman correlation.Results revealed that their academic adequacy level on their knowledge of the subject matter and teaching approaches and strategies are Fairly Adequate,Much Adequate in their knowledge of the preparation of instructional materials and Slightly Adequate in their knowledge of the curriculum and knowledge of classroom management which contributed to an over all Fairly Adequate level.Their place of residence shows relationship to their knowledge of preparation of instructional materials while exposure to electronic media and school facilitiesare related to their knowledge of classroom management.
\end{abstract}

Keywords:

academic adequacy,curriculum,classroom management,knowledge of the subject matter,pre-service teachers

Article Received: 18 October 2020, Revised: 3 November 2020, Accepted: 24 December 2020

\section{INTRODUCTION}

Good teachers are critical to the success of people in every profession.No microcomputer will replace them, no television system will clone them and distribute them, no scripted lessons will direct and control them, no voucher system will bypass them[1].Teachers in a global classroom must possess a high degree of expertise in content and pedagogy [2].The statements was affirmedby Choy et al.[3] that from the beginning of their formation as teachers they should be equipped with the necessary knowledge and skills for them to teacheffectively in the future.

The most important contributing factor to improve thequality of education is identified as the professionalcompetence of educators[4].Gendall [5] andLingam [6] further explained that the teachers' preparation and the courses that they undergo in the preservice teacher education determine the teachers' professional competence.

Secondary Pre-Service teachers, duringtheir practicum,start to master their area of
specialization.The English major pre-service teachers, therefore, are expected to be ready and equipped during this stage.Admittedly,there are barriers alongthe way and this is their mastery of their subject matter and full knowledge of the different pedagogies.As rightly argued by Enginarlar[7],the dissatisfaction with the quality of teaching English is generally ascribed to teacher education programs at universities, and among many essential components of these programs, the practicum, in which last year teacher trainees observe mentor teachers in real classrooms and do practice teaching to real students, has an enormous impact on upgrading the quality of teachers and thus language teaching in general.

TheBachelor of Science in Education major in English(BSEd-English) is a four year degree program in the education curriculum that prepares the pre-service teachers teach English subjects in high school.Taking this as a major subject to teach prepares them to get a closer look at the 
development of linguistics,the structure of the English language and the differenttypes of literature(American,English,Afro-Asian) that flourished throughout the centuries.Enrolling this course allows students to be exposed in various courses

likeDevelopmental

Reading,CampusJournalism,Language and literature Assessment to mention a few of them.This alone gives us the understanding that English as a major subject is complex and multidimensional.Thus,pursuing this as an area of specialization requires a student to be interested,inclined, and knowledgeable in the subject.

As described by Tuli and File[8],practicum teaching experiences among pre-service teachers are the most important part of teacher education program.Many students in teacher education programs teaching in real classrooms for the first time considered it as an "opportunity for pre-service teachers to apply theoretical knowledge and skills, previously gained in the teacher education classroom, to authentic educational settings"[9].

However, this practicum generates various challenges that pre-service teachers will face. Issues such as overcrowded classrooms, students at different levels of language proficiency[10], “classroom discipline, assessing students' works, the organization of class work, relationships with parents, and insufficient and/or inadequate teaching materials" [11] often plague teachers when they first enter the teaching profession.

Durgunoglu and Hughes[12] conducted a study to investigate how prepared are pre-service teachers in the U.S to teach English language learners. Theresearchers concluded from 'study 1' of classroom observation that the student teachers were not well prepared to teach English language learners although some of the pre-service teachers rated themselves as moderately prepared from the second study of knowledge test. In the same vein,Ganal et al.[13]analyzed the problems the students encountered during practice teaching. Findings disclosed that the problems and difficulties encountered relate to homesickness, financial adjustment, family, learners, classroom management, communication skills, instructional skills, instructional materials and evaluation tools preparation and analysis of test results, different feelings and emotions, and on adjustment to the cooperating school as a whole.Corroborating these results,Paghasian[14] revealed that the fourth year BEEd students had an outstanding performance in personal - professional preparations, classroom management and had good performance in practice teaching, but average in English and Filipino languages.

It is interesting to note that commonalities ofresults were obtained from the previousstudies conducted along pre-service education.Further,results of the previous studies affirm that the teaching professionis currently facing severalchallenges; the global economy and competitive market place, the changing nature of job and advanced technology, changesindemographic nature of students and the growing bodies of knowledge about how people learn and what makes for effective teaching have caused teachereducation to re-examinethebasic principles and methodologies of teacher preparation[15].

Darling-Hammond and Baratz-Snowden[16] emphasized that efforts to increase teachers' proficiency and efficacy are critical components in making necessary changes to the education system.Beginning teachers should have basic knowledge and skills of the pedagogical principles and the content knowledge in selected subject areas upon completion of their pre-service teacher education programme.

Thus,this study highlighted the level of the adequacy of thepre-service English teachers in terms of their knowledge of thesubject matter,teaching approaches and strategies,preparations of instructional materials and classroom management.

\section{LITERATURE REVIEW}

The practicum is an important yardstick in teaching profession courses. The practicum or teaching practice component is central to all 
teacher educational programmes[17].It marks the time that pre-service teachers get to be supervised in their teaching practice components in schools[18].They would face the real classroom situation and apply the teaching theories, techniques and methods that they have learnt throughout

their courses. The current trend of the practicum carried out by most higher education institutions is to have a collaboration with the schools which play a part in teacher training because pre-service teachers will have the chance undergo practicum in their school.

Nunan[19]gave an overview of the classroom practices in teaching. He said that "classrooms informed by current views on language pedagogy will involve a change in teaching approach away from a high-structure orientation towards a more low-structure orientation". While Haigh, Pinder, McDonald[20] noted that if student-teachers were active on the actual practice teaching experience and with the constant guidance from their associate teachers, they would learn the art of teaching.Gan[21] found out that the pre-service teachers' practicum experience was not that good as they encountered difficulties applying the theory they learned in their BEdEl program in the actual classroom teaching.

\subsection{KNOWLEDGE OF THE SUBJECT MATTER}

Until a few years ago, the subject matter knowledge of teachers was largely taken for granted in teacher education as well as in research on teaching. Recent research, focused on the ways in which teachers and teacher candidates understand the subjects they teach, reveals that they often have misconceptions or gaps in knowledge similar to those of their pupils[22,23]. This paper argues that as teachers are themselves products of elementary and secondary schools in which, research has shown, pupils rarely develop deep understanding of the subject matter they encounter, hence,reveals teachers' inadequacy on subject matter preparation.More than this, pre-service teachers mastery of the subject matter when they teach manifests quality
teaching.PedagogicalContentKnowledge(PCK)as Karaman[24] thinks that this moment is one of the most criticalelements of improving teacher quality.Ball[25]bemoaned the division of subject matter and pedagogy intheconceptualization of the curriculum of teacher education as she considered the knowledge of subject matter as being central to the core tasks of teaching.

Subject Matter Knowledge (SMK) can be said to be at the very heart of teachers' practice - all teachers teach something. Hence a starting point to equip all teachers would be to ensure that they know the material they have to teach. Where there is widespread agreement about what is to be taught, a large part of preparing people to teach the material becomes a case of making sure they know the material well enough to pass it on to others\{26].Stevens and Wenner[27] who tested prospective primary teachers (in the USA) for science and mathematics SMK and beliefs and found that they underperformed in science SMK while their mathematics SMK was at a more acceptable level. Abd-El-Khalick[28]explored the subject matter structures of preservice and experienced teachers with regard to photosynthesis and conceptions of biology and found that while their subject matter structures globally fell on a continuum from poorly articulated to well integrated, their topic specific subject matter structures were clearlydifferentiated between the pre-service and the practicing teachers. When teachers possess inaccurate information or conceive of knowledge in narrow ways, they may pass on these ideas to their students. They may fail to challenge students' misconceptions; they may use texts uncritically or may alter them inappropriately. Subtly, teachers' conceptions of the knowledge shape their practice -the kinds of questions they ask, the ideas they reinforce, the sorts of tasks they design. Although early attempts to validate these ideas, to demonstrate empirically, the role of teachers' subject matter knowledge, were unsuccessful [29].

\subsection{KNOWLEDGE \\ OF \\ TEACHING}


Even with the concerns identified in previous research, it is critical to examine the concerns of pre-service and in-service teachers' specific to the current classroom environment. An ever-changing educational climate contributes to a change in types and levels of concerns experienced by teachers.A more thorough knowledge of present concerns and deeper examination of how concerns change throughout a pre-service education program will allow teacher educators to assist pre-service students in developing a greater understanding of appropriate instructional strategies, course sequencing, and personal efficacy that will contribute to teacher success upon entering the field[30].

Pre-service teachers need to be competitive as early as they should be. Therefore, there is a need to strengthen teacherpreparation.Darling-Hammond[31]callsit "well-supervised clinical practice as a critical element of effective preparation". She outlines further in her article the challenges to creating productive clinical experiences for prospective teachers and identifies strategies that have been found successful in confronting these challenges. These include the development of professional development school relationships that strengthen practice in partner schools and the use of teacher performance assessments that focus attention on pulling together practical skills and providing feedback to candidates and programs.

Rosenshine and Frust[32] as cited in the study of Shinn[33] reported students learn best when the following characteristics are present:(1)variability in teachingmethods and materials,(2) interest,(3)clarity,(4)task-oriented

behaviour,(5)multiple levels of questions,(6)student opportunity to learn the material,(7)multiplelevels of questions, and,(8)enthusiasm.Yelon[34]promoted the ten powerful instructional principles that he believed excellent teachers apply which are: meaningfulness, prerequisites, open communication, organized essential ideas, learning aids, novelty ,modelling, active, appropriate practice, pleasant conditions and consequences, and consistency.

\subsection{KNOWLEDGE ON THE PREPARATION OF INSTRUCTIONAL MATERIALS}

Cunningham[35]summarizes the role of material in language teaching as a resource for presentation materials, source of activities for learner practice and communicative interaction. Tomlinson[36] believes that materials should achieve impact and should help the learners to feel at ease. What is being taught should be perceived by learners as relevant and useful. Materials should expose the learners to language in authentic use. However, resources such as knowledge and skill may be limited for preservice teachers. Due to their inexperience, preservice teachers may have a narrow view of teaching and classroom practice, and limited or incomplete conceptions of the ways in which curriculum materials can be utilized.Moreover, preservice teachers bring preconceptions about teaching into their teacher education programs[37,25].

Findings in the study of Paghasian[14] revealed that most of the pre-service teachers are ready to make visual aids and other instructional materials and have the ability to develop the lesson in relation to the objectives.

Generally,there was the view that the graduates from the teachers' college programme should be able to plan classes to meet the specific needs of the pupils in their charge; present interesting and innovative lessons that are mainly student-centred, and which make adequate use of teaching resources; manage their class well; and administer appropriate evaluation tasks[15]All of the lecturers emphasized the pivotal role that resources play in the teaching/learning enterprise. They were of the view that trainees should be able to make effective use of resources (preferably low-cost resources) in their teaching.

Ganal et al.[13]narrated that pre-service teachers experience problems and difficultiesin selecting, preparing and utilizing instructional materials which are diverse, flexible, objective, multidimensional etc. to satisfy individual differences in learning. The problems identified are the same problems the respondents 
encountered during practice teaching conducted by Samson[38] and Saricoban[10].

\subsection{KNOWLEDGE OF THE CURRICULUM}

Basturk et al.[39] emphasized that one of the componentsofpedagogical content knowledge is curriculum knowledge. Curriculum contains aims and objectives which belong to the subjects that the teachers will teach and explain the skills that students are supposed to be obtained.The result of their study that investigated the knowledge of the pre-service teachers in curriclum revealed that respondents' adequacy in curriculum is limited.Similar results were obtained in the study conducted by Canbazoglu[40] with the science pre-service teachers.

The findings of the study of Biong[41] cite that teacher education students are effective facilitators of student learning as they help students learn the desired curriculum objectives. For pre-service teachers, the highest rating is on the"setting of appropriate learning goals"; whereas, for the cooperating teachers, the highest rating is on"planning lessons to fit within available instructional time". Corpuz and Salandanan[42] emphasize that a definite lesson objective preempt teachers from losing sight of what they intend to teach. Moreover, the pre-service teachers properly manage the time as they are seen by the cooperating teachers to be very capable of designing lessons that are time-bound. According to Acero, Javier and Castro[43],an effective teacher allocates and controls the time for instruction as well as the rate of student engagement in the learning activities.

School of thought have approved curriculum development in three different ways.For

Tyler[44],curriculum development isa technical production procedure.it is therefore interestedin technical questions that approach curriculum development as objective,scientificand drivenby"means and reasoning" or "rational decision making".

ForStenhouse[45],however,curriculum

development is a process and is socially constructed. Teachers are involved in the process of developing a curriculum that takes account ofcontextual factors rather than pre-specifyingobjectives.Curriculum involves critical reflection, problems posing and dialogue. One way of developing a curriculum from a critical approach is to use themes addressing social, economic and or political issues and use this to embrace homogenic and ideological curriculum questions within a critical interest.

2.5KNOWLEDGEOF

CLASSROOM MANAGEMENT

Classroom management has been defined as the "actions taken to create and maintain a

learningenvironment conduciveto successful instruction" [46].It is a major contributor to effective teaching and learning process in the classroom. Poorclassroom management frequently linked to misbehaviors that interfere with teaching and learning and produce tremendous stress[47].It follows that classroommanagement should not be seen as synonymous with classroom discipline; it involves those other aspects mentioned above that are equally inherent to teaching. Crookes[48] similarly sees a well-managed classroom as a relatively orderly room in which "whatever superficial manifestations of disorder that may occur either do not prevent instruction and learning, or actually support them" (p. 144). What the above definitions of classroom management have in common is establishing an appropriate environment and therefore order in the classroom so that teaching and subsequently learning can take place.

Teachers who are skillful with classroom management are able to handle students' behavior issues well. Many studies showed teachers who demonstrate a good knowledge and understanding of behavior management could handle this situation confidently and positively[49,50].

Certo's[51] study with beginning teachers and their mentors found that classroom management and discipline were perceived as challenging.Ullah[52] affirms that one of the challenges that the student-teachers faced in their practicum teaching was classroom management. Since they were just practicing teachers, they did not have enough knowledge on how to manage a 
number of students in the class. This challenge was confirmed in the result of the study of Raba[53]which suggested that less experienced teachers of English in Palestine are facing a crisis in their capacity to practice effective classroom leadership and management. They appear to feel that both their pre-service training and their in-service support from school leadership and experienced teachers have done little to prepare or support the for managing classroom.

In a study conducted by Gialloand Little[54] on 54 elementary teachers with less than three years of teaching experience and 25pre-service teachers in their final year teaching program, both groups reported feeling only moderately prepared and indicated that they required additional education in classroom management,the same finding was confirmed by Maskan[55] citing that pre-service teachers were moderately prepared and indicated that they required additionaleducation in classroom management.

Same results were obtained in the studies of Gan [21]; Coskun[56]; and Yusof et.al.[57].Controlling the students' noise, dealing with misbehaviors, and the likes are just few of the problems that student-teachers experienced during their actual teaching. Some student-teachers found it difficult to start, to motivate and to prepare their students for the day's lesson since their students were not enthusiastic upon seeing them in the classroom. Coskun[56] said that student-teachers have difficulty managing the classroom because of the fact that they are not considered to be real teachers. Although, the real course teacher was in the classroom, students knew that the one taking over their class was also a student like them.Laruan[58] identifiedthe problems and difficulties student teachers encountered which are: teachers'personal preparation that includes emotional and social aspect of the student teacher; teachers' professional preparation that includes class participation, school adjustment,problemsin workloads and guidance problems; and classroom management that includes instructional and evaluation problems.

\subsection{RESEARCH QUESTIONS}

This study sought to determine the following objectives:

1.To determine the profile of the respondents along:
A. Student-Related Profile
a. Age,
b. Sex,
c. Civil status,
d. Religion,
e. Place of residence,
f. Parents' educational attainment,
g. Number of siblings in the family
h. Birth order
i. Membership in organization, and
j. Exposure to mass media?
B. School-Related Profile
a. Availability of Facilities
2. To assess the academic adequacyof the respondents along:

a. Knowledge of the subject matter,

b. Knowledge of teaching approaches and strategies,

c. Knowledge on the preparation of instructional materials,

d. knowledge of the curriculum, and

e. Knowledge of classroom management

\section{TO DETERMINE THE SIGNIFICANT RELATIONSHIP BETWEEN ACADEMIC ADEQUACY AND:}

a. Student-related profile and

b. School-related profile

Methods

\subsection{Research Design}

This study is a descriptive research employing correlational approach.It described the profile andthe level of adequacy of the pre-service English teachers' knowledgeon subject matter, approaches andstrategies, preparation of instructional materials,curriculum and classroommanagement.The correlational approach was used in determining the relationshipbetween the profile and the academic adequacy of the respondents. 


\subsection{Population and Locale}

Using total enumeration, the respondents were the 21English major pre-service teachers who were enrolled for the school year 2016-2017 in the two campuses of Ilocos Sur Polytechnic State College,Sta.Maria and Tagudin Campus respectively.There were 12 respondents from Tagudin and nine (9) English major students from Sta.Maria campus.

\subsection{Data Gathering Procedure}

The researcher obtained the data on information through profiling while their academic adequacy was assessed utilizing a teacher made test adopted from Ibanez[59] which composed of these parts: 250 item test thatis comprised of the following components: Knowledge of the subject matter with 190 items covering the content of the BSEd English Curriculum and 15 items each on knowledge of approaches and strategies,knowledge of thepreparation of instructional materials,knowledge ofthe curriculumand knowledge of classroom management.The test was a multiple choice type of test.The researcher administered the test inside the classroom. Time allotment for each part of the test was observed.

\subsection{Statistical Treatment of Data}

Frequency Count and Percentagewas employedin describing the profile and the adequacy level of the pre-service English teachers.Mean was used to determine the homogeneity and heterogeneity of the scores obtained by the respondents in the achievement test.Pearson Product Momentof Correlation,chi-square and spearman correlation were employed to determine the significant relationship between the profile and the academic adequacy of the respondents.

\subsection{Data Categorization}

Level of Academic Adequacy

Range of Rating Descriptive Rating

201-250 Very Much Adequate

151-200 Much Adequate

101-150 Fairly Adequate

51-100 Slightly Adequate

1-50 Not Adequate

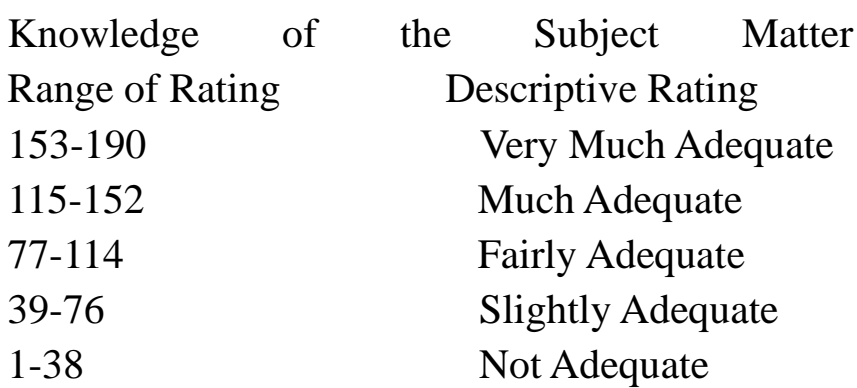

Knowledge of Teaching Approaches and Strategies, Curriculum, Classroom Management

$\begin{array}{lr}\begin{array}{l}\text { Range of Rating } \\ 13-15\end{array} & \begin{array}{r}\text { Descriptive Rating } \\ \text { Adequate }\end{array} \\ 10-12 & \text { Much Adequate } \\ 7-9 & \text { Fairly Adequate } \\ 4-6 & \text { SlightlyAdequate } \\ 1-3 & \text { Not Adequate }\end{array}$

\section{RESULTS AND DISCUSSIONS}

This chapter presents the presentation, analysis and interpretations of data, summary of findings, conclusions and recommendations.

\section{A. Student Related Profile}

As revealed in the study, majority of the respondents belong to the age bracket of 19-20 with $\quad 66.67 \%$ of the total sample. It is followed by the students whose ages are from 21 and above with $33.33 \%$. This implies that respondents are in normal age parallel to their year level.Same finding was observed in the study of Ganal et al.[13].

Sex. Dominating the table in termsof sex are thefemale respondents with a frequency

equivalent to 13 or $61.90 \%$ of the total. The male respondents on the other hand, haveeight $(8)$ or38.10\%.Consideringthe population of the schools, there are more female enrolleesthan the male. The result suggests that female respondentsare more attracted to teaching profession. In supportto this findings, the study of Ramos[60]revealed the same result where there are more female respondents than male.Capa and 
Cil[61] showed that gender was not effective on the pre-serviceteachers' attitude towards teaching profession, but in the sub dimensions of loving profession and respect to profession, females had more positive attitude than males.

Civil Status. Respondents'civil status as reflected, has a frequency of 20 or $90.48 \%$ are single while only one or $4.76 \%$ is married. These result discloses that students' respondents prefer to be single while studying. The study of Amudal et al.[62]obtained the same result where there are moreunmarried respondents over married.This study investigated marital status and age as predictors of students' academic performance in the North-eastern states of Nigeria.

Place of Residence. Majority of the respondents live in a rural area with a total of 19 or

$90.48 \%$ while only two of the sample live in an urban area. This result implies that most of the clients of the schools, Sta.Maria and Tagudin respectively reside inthe different barangays in the town where the two campuses are situated.According to Upcraft, Gardner, Barefoot, and Associates[63], the place of residency will influence the likelihood of making an easy transition into the campus environment, succeeding academically, matriculating through to

graduation, and having a fulfilling educational experience.

Parents Educational Attainment.The highest recorded count and percentage is 12 or $57.14 \%$ which belongs to the respondents whose fathers are high school graduate followed by those who reached college with 7 or $28.58 \%$. Since the largest number of fathers in terms of educational attainment achieved high

school diploma, most of them are working abroad as skilled workers and farmers. Mother's education on the other hand reflects a $38.10 \%$ of the total samplerespondents have reached college level followed by $23.81 \%$ whose mothers

finished high school while $19.05 \%$ reached high school level.The least tallied frequency belongs to the mothers whose education is elementary graduate andcollegegraduatewith $\quad 4.6 \%$ respectivey.Mbuguaetal.[64]holdsthe same findings.Majority of his respondents have parents who have achieved their high school diploma. This result negates the findings of

Young and Smith[65] where it revealed that since 1970s the average educational level of parents has been increasing. This is an indication that there is a change in the family's ability to support and encourage education for their children.

Number of siblings in the family.Respondents whose family members ranges from 2-3 registered to have the highest frequency count with $47.62 \%$ followed by $38.10 \%$ of the respondents belong to a family with 4-5 members. Two or $9.52 \%$ were only child and only one or $4.76 \%$ has a family number of 6 and above.This implies the preference of the family to only have a minimal number of children for a responsible prenthood.The study of Draugh[66] revealed that greatest percentage of his sample belong to a family with one child followed by a famiy with two children.

Birth Order. The middle children in their family surfaced as the most numbered respondents comprising a total of 47.62 .Following are the eldest children, only child and youngest child in the family, with $38.10 \%, 9.52 \%$ and $4.72 \%$ respectively.These findings negate the result of the study by Draugh[66] which disclosed that the first born children (as determined by biological placement) had the highest frequency and middle child was the second highest.Not only several can birth order be used as purely an academic variable but several links proposed between birth order and behavioral deelopment suggest that it could also be used within the educational and familialsettings[67-69].

Membership in Organization. School paper and English Club registered to be the respondents' preference when it comes to membership in anorganization with $40.00 \%$ followed by

Filipino Club and Sports Club with $10.00 \%$ respectively.This implies that the respondents 
preference to organizational affilaiation reflects their interest.Involvement in clubs and organizationshas been shown to correlate positively with several areas of psychosocial development. Specifically, college juniors who are members of student organizations score higher than nonmembers on such factors as educational involvement, career planning, lifestyle planning, cultural participation, and academic autonomy[70].

Exposure to Mass Media.The result shows that under printed materials,magazines received the

highest distribution with $22.09 \%$ followed by newspapers and books with $20.93 \%$.These were the top threemedia the respondents are exposed to while tabloids and journals received the lowest frequency witth $17.45 \%$.This implies that respondents rely mostly on printed materials that are accessed easily when doing their assignments and researches in the library.Television with $27.94 \%$ followed by radio with $25.00 \%$ are the media that respondents are accessed easily when doing their assignments and researches in the library.Televisionwith

$27.94 \%$ followed by radio with $25.00 \%$ are the media that respondents are exposed to when it comes to electronic media. Motion picture and internet appeared to be accessiblealso by the respondents as registered $23.53 \%$.This result implies that most households own television

and radio.Tilson and Bekele[71] outline Ethiopia's three decades of experience in using television and radio broadcasts to improve the quality of education in the country, for example,

by supplementing the curriculum and improving access to education. Similarly, Michel and Thomas[72] note the effectiveness of television as an inexpensive, culturally relevant medium for teaching children in Haiti.

Table 2 School-Related Profile

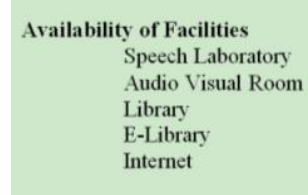

$\begin{array}{ccl} & 15 & 19.48 \\ & 18 & 23.38 \\ & 20 & 25.97 \\ & 6 & 7.79 \\ & 18 & 23.38 \\ \text { Total } & 77 & 100.00\end{array}$

Availability of Facilities. Twenty or $25.97 \%$ of the respondents revealed that library is available in their campus followed by Audio Visual Room and Internet with a frequency of 18 or $23.38 \%$.The availability of Speech Laboratory is evident with a frequency of 15 or $19.48 \%$ while

6 or 7.79 of the respondents claimed that E-Library is available in the school. The data provides the adequacy of physical resources available in their campuses.The study of Cynthia \& Megan[73]confirmed a strong and positive relationship between quality of school facilities and student achievement in English and Mathematics.Bandele[74] noted that the importance of physical facilities cannot be relegated. Facilities like modern laboratories, libraries and classrooms are to be put in place in all our schools. Adesola[75]found out that the level of available resources is indeed a plus to the teachers toward effective delivery of lesson.

Table 3 Academic Adequacy level of the Pre-Service Student-Teachers

\begin{tabular}{|c|c|c|c|c|c|c|}
\hline & $\begin{array}{l}\text { Number } \\
\text { of Items }\end{array}$ & $\begin{array}{l}\text { Range of } \\
\text { Scores }\end{array}$ & & Frequency & Percentage & $\begin{array}{l}\text { Descriptive } \\
\text { Rating }\end{array}$ \\
\hline Knowledge of & 190 & $77-114$ & & 15 & 71.43 & FA \\
\hline \multirow[t]{2}{*}{ Subject Matter } & & $39-76$ & & 6 & 28.57 & SA \\
\hline & & & Total & 21 & 100.00 & \\
\hline Knowledge of & 15 & $7-9$ & & 12 & 57.14 & $\mathrm{FA}$ \\
\hline \multirow{3}{*}{ and Strategies } & & $4-6$ & & 9 & 42.86 & SA \\
\hline & & & Total & 21 & 100.00 & \\
\hline & 15 & 10-12 & & 19 & 90.48 & MA \\
\hline Knowledge on the & & $7-9$ & & 2 & 9.52 & $\mathrm{FA}$ \\
\hline $\begin{array}{l}\text { Preparation of } \\
\text { Instructional }\end{array}$ & & & Total & 21 & 100.00 & \\
\hline \multicolumn{7}{|l|}{ Materials } \\
\hline \multirow{4}{*}{$\begin{array}{l}\text { Knowleage of the } \\
\text { Curiculum }\end{array}$} & 15 & $7-9$ & & 11 & 52.38 & FA \\
\hline & & $4-6$ & & 6 & 28.57 & $\mathrm{SA}$ \\
\hline & & $1-3$ & & 4 & 19.05 & $\mathrm{NA}$ \\
\hline & & & Total & 21 & 100.00 & \\
\hline Knowledge of & 15 & $7-9$ & & 12 & 57.14 & $\mathrm{FA}$ \\
\hline Classroom & & $4-6$ & & 3 & 14.29 & $\mathrm{SA}$ \\
\hline \multirow[t]{2}{*}{ Management } & & $1-3$ & & 6 & 28.57 & $\mathrm{NA}$ \\
\hline & & & Total & 21 & 100.00 & \\
\hline \multirow[t]{3}{*}{ OVER-ALL } & 250 & & & 19 & 90.48 & \\
\hline & & $51-100$ & & 2 & 9.52 & $\mathrm{SA}$ \\
\hline & & & Total & 21 & 100.00 & \\
\hline & & & Neyy Mus & ch Adequate (VM & & \\
\hline $151-200$ & $115-152$ & 10-12 & & & & \\
\hline $101-150$ & $77-114$ & 7.9 & Faily A & dequate $(F A)$ & & \\
\hline $\begin{array}{l}51-100 \\
1-50\end{array}$ & $\begin{array}{l}\begin{array}{l}39.76 \\
1.35\end{array} \\
-\end{array}$ & $\begin{array}{l}1.6 \\
1.3\end{array}$ & $\begin{array}{l}\text { Slightly } \\
\text { Not } A d x\end{array}$ & $\begin{array}{l}\text { Adequate } \\
\text { equate }(\mathrm{NAA})\end{array}$ & & \\
\hline
\end{tabular}

Table 3 discloses the adequacy level of the pre-serviceteachers majoring in English along; Knowledge of the Subject Matter,Knowledge of the

Subject Matter,Knowledge of Approaches and Strategies, Knowledge on the Preparationof Instructional Materials,Knowledge of the Curriculum and Knowledge of Classroom Management.

Knowledge of the Subject Matter. The results show that 15 or $71.43 \%$ of the respondents are 
Fairly Adequate in their knowledge of the subject matter while six or $28.57 \%$ are Slightly

Adequate. This result suggests that pre-service teachers are insufficientin their knowledge of the English content.

This result is quite similar to the study of Durgunoglu and Hughes[12] who investigatedthe preparedness of the pre-service teachers in the U.S to teach English language

learners.Theresearchers concluded from 'study 1' of classroom observation that the student teachers were not well prepared to teach English language learners although some of the pre-service teachers rated themselves as moderately prepared from the second study of

knowledgetest.Peters[76] emphasized that if anything is to be regarded as a specific

preparation for teaching, priority must be given to a thorough grounding in something to teach. Buchman[77] affirms that the subject matter is an essential component of teacher knowledge is neither a new nor a controversial assertion. After all, if teaching entails helping others learn, then understanding what is to be taught is a central requirement of teaching.Mohamed et al.[78] suggested that a more specific approach to readiness would refer to an optimal level of professional competences development that would allow future teachers to assume job responsibilities in an effective way.Relative to these views,Park et al.[79] identified knowledge, attitudes and interests as speciic elements of teaching readiness. In addition, these pillars are considered to be vectors of teaching efficacy.

Knowledge of Teaching Approaches and Strategies

The data reveal that 12 or 57.14 are Fairly Adequate while nine(9) or 42.86 of the respondents are Slightly Adequate on their Knowledge of Teaching Approaches and Strategies. This result manifests respondents'unfamiliarityof the teaching approaches and strategies that are appropriate and necessary in lesson preparation. English as a subject to teach requiresapproaches and strategies that may vary from other field of specialization.Relative to this result,the study of Ulla[52]revealed that when student-teachers were asked in the interview as to the reason why they used those techniques(paired activity, small group activity, message relay and others) and strategies in their actual classroom teaching, they disclosed that they only imitated what they observed from the other English teachers in their actual classroomobservations. They did not have other resources to make their lessons effective and enjoyable other than what they already knew and learned. The lackof teaching resources and teaching ideasprompted the student-teachers to recycle the strategies and methods they learned during their in-class practice teaching. According to Carkhuff[80], teaching is the opportunity to help others to live their lives fully, which means we help to give to our learners' lives through their physical, emotional, intellectual and social growth. Anderson[81] concluded that student student outcomes may heavily depend on the teacher's instructional planning, teaching method selection, and having a variety of learning activities.

Knowledge of the Preparation of Instructional Materials

Based from the result, 19 or $90.48 \%$ of the respondents are Much Adequate in their knowledge of the Preparation of Instructional Materials while only two or $9.52 \%$ are Slightly Adequate. This result manifests that pre-service teachers have adequate knowledge ofof the different theories and principles governing the preparation and evaluation of instructional materials.This also implies the interest of the future teachers to be creative and resourceful in the preparation of IMs.Many pre-service teachers consider the advanatge of these IMs in the delivery of their lesson.Cunningham[35] summarizes the role of material in language teaching as a resource for presentation materials, source of activities for learner practice and communicative interaction. Tomlinson[36] believes that materials should achieve impact and should help the learners to feel at ease, What is 
being taught should be perceived by learners as relevant and useful. Materials should expose the learners to language in authentic use.

\section{Knowledge of the Curriculum}

Majority of the respondents as indicated by the frequency of 11 or $52.38 \%$ are Fairly Adequate while 6 or $28.57 \%$ are Slightly Adequate and four or $19.05 \%$ are Not Adequate in their knowledge of the Curriculum. Evidently,the respondents obtained low scores which implies their inadequacy on curriculum topics. Thus, inadequacy in the content of the testwhich covered the provisions concerning the development of curriculum lifted from CMO No.30, series of 2004-undergraduate teacher education guidelines[82] which areprimarily taught in the professional subject,Curriculum Development.Their unfamiliarity to the different approaches in curriculum development as learned theoretically is appeared to be a factor to their inadequacyin thisarea.ForTyler,[44]curriculum development is a technical production procedure.it is therefore interested in technical questions that approach curriculum development as objective, scientific and driven by "means and reasoning" or "rational decision making".

\section{Knowledge of Classroom Management}

Result reveals that 12 or 57.14 are Fairly Adequate in their knowledge of classroom management, six or 28.57 are Not Adequate and three or $14.29 \%$ are slightly adequate. The result manifests their abilty to address situations that require their skill in classroom management. Although majority are fairly adequate in their knowledge of classroom management, still there are pre-service student-teachers who are inadequate in this aspect. This result conforms Stoughton[83] who revealed that classroom management was identified by pre-service teachers "as a subject about which there is a fairly wide disparity between what is taught in university classes and seminars and the theoretical construct upon which many behavioral plans are based" (p. 1026). This same result was found by Gan[21]; Coskun [56]; and Yusof et.al[57] in their studies. Controlling the students' noise, dealing with misbehaviors, and the likes

just few of the problems that student-teachers experienced during their actual teaching.

Some student-teachers found it difficult to start, to motivate and to prepare their students for the day's lesson since their students were not enthusiastic upon seeing them in the classroom. Coskun[56] said that student-teachers have difficulty managing the classroom because of the fact that they are not considered to be real teachers. Although, the real course teacher was in the classroom, students knew that the one taking over their class was also a student like them.

Table 4 Over all Academic Adequacy Level of the Pre-Service Teachers

\begin{tabular}{|c|c|c|c|c|c|c|}
\hline \multicolumn{4}{|c|}{ 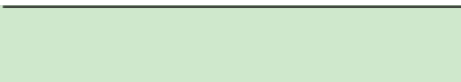 } & $\begin{array}{l}\text { Number of } \\
\text { Items }\end{array}$ & $\bar{x}$ & DR \\
\hline \multicolumn{4}{|c|}{ Knowledge of Subject Matter } & 190 & 86.05 & FA \\
\hline \multicolumn{4}{|c|}{$\begin{array}{l}\text { Knowledge of Teaching Approaches } \\
\text { and Strategies }\end{array}$} & 15 & 6.67 & FA \\
\hline \multicolumn{4}{|c|}{$\begin{array}{l}\text { Knowledge on the preparation of } \\
\text { Instructional Materials }\end{array}$} & 15 & 10.24 & MA \\
\hline \multicolumn{4}{|c|}{ Knowledge of the Curriculum } & 15 & 5.71 & SA \\
\hline \multicolumn{4}{|c|}{ Knowledge of Classroom Management } & 15 & 5.10 & SA \\
\hline \multicolumn{4}{|c|}{ TOTAL } & 250 & 113.77 & FA \\
\hline $\begin{array}{l}\text { Legend: } \\
\begin{aligned} & 201-250 \\
& 151-200 \\
& 101-150 \\
& 51-100 \\
& 1-50\end{aligned}\end{array}$ & $\begin{array}{l}154-190 \\
115-152 \\
77-114 \\
39-76 \\
1-38\end{array}$ & $\begin{array}{l}13-15 \\
10-12 \\
7-9 \\
4-6 \\
1-3\end{array}$ & $\begin{array}{l}+ \\
\text { Very } \\
\text { Much } \\
\text { Fairly } \\
\text { Sligh } \\
\text { Not } A\end{array}$ & $\begin{array}{l}\text { fuch Adequate (VI } \\
\text { Adequate (MA) } \\
\text { Idequate (FA) } \\
\text { y Adequate (SA) } \\
\text { equate (NA) }\end{array}$ & & \\
\hline
\end{tabular}

Table 5 presents the over-all level of academic adequacy of the respondents. It discloses that the pre-sevice teachers majoring in English have a Fairly Adequate level as indicated by a grand total mean of 113.77.This is supported by the Fairly Adequate Knowledge of the Subject Matter and Teaching Approaches and Strategies with means of 86.05 and 6.67 respectively.Following this result,respondents show Much Adequacy on the preparation of instructional materialwith 6.67 as a mean . However, they are Slightly Adequate along Knowledge of the Curriculum and

Knowledgeof Classroom Management with 5.51 and and 5.10 ranges of scores respectively.Their Fairly Adequate level in general is attributed to the their inadequacy on their knowledge in classroom management and 
curriculum. Their knowledge of the curriculum lies in their understanding of the curriculum development and on the content and implementation of the undergraduate teacher education curriculum based on the guidelines of CMO No.30,series of 2004[82].There are items in the test that they failed to answer correctly. On classroom management. The test items provided to them are classroom situationsto test how pre-service teachers quickly respond to the given circumstances.

Most of their answers are incorrect showing their lack of knowledge on the application of the theories and principles of classroom management. However, this finding negates the result of the research conducted in Malaysia by Bari, Yasin, and Hamzah[84] . According to the researchers, pre-service teachers master good theoretical knowledge about behavior management.But the study of Ganal et al.[13]asserts that managing a classroom independently has been the most frequent problem that the student teachers encountered.Pre-service teachers manifest inability to hold attention of the pupils and students throughout the period of time.

The result of the present study conforms with Certo's [51]study with beginning teachers and their mentors.It discloses that classroom management and discipline were perceived as challenging. A number of approaches have been proposed to help teachers address classroom management in their lessons. Wolfgang and Glickman[85] talked about three categories for problem solving in classroom practice: relationship/listening,rules/rewards, andconfrontin g/contracting.

Table 5 Summary of correlations between the profile and level of academic adequacy

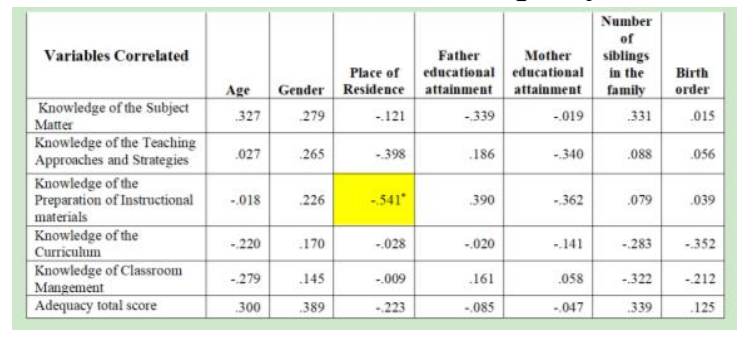

Results of the Pearson correlation indicate that there is a significant negative association between knowledge of preparation of instructional materials and place of residence, $(r(19)=-0.54, p$ $=.011)$. Rural place of residence is coded 1 and urban is coded 2. The negative correlation implies that students from rural areas tend to have higher score in knowledge in the preparation of instructional materials. This result is attributed to the fact that students coming from rural areas live a life that is simpler and slower compared to the students living in urban places. These students are more exposed to recreation amenities where they can spend some of their time.Unlike students in rural areas who have ample time to master their lessons that eventually enhance their knowledge.According to Upcraft, Gardner, Barefoot, and Associates[63], the place of residency will influence the likelihood of making an easy transition into the campus environment, succeeding academically, matriculating through to graduation, and having a fulfilling educational experience.

Table 6 Summary of correlations between the profile and level of academic adequacy

\begin{tabular}{|l|r|r|r|}
\hline \multicolumn{1}{|c|}{ Variables } & $\begin{array}{c}\text { Eletronic } \\
\text { media } \\
\text { used }\end{array}$ & $\begin{array}{c}\text { Print } \\
\text { media } \\
\text { used }\end{array}$ & $\begin{array}{c}\text { School } \\
\text { facilities } \\
\text { available }\end{array}$ \\
\hline $\begin{array}{l}\text { Knowledge of the } \\
\text { Subject Matter }\end{array}$ & 1.071 & 3.124 & 3.871 \\
\hline $\begin{array}{l}\text { Knowledge of the } \\
\text { Teaching Approaches and } \\
\text { Strategies }\end{array}$ & 1.452 & 5.162 & 5.904 \\
\hline $\begin{array}{l}\text { Knowledge of the } \\
\text { Preparation of } \\
\text { Instructional materials }\end{array}$ & 1.358 & 5.597 & 2.480 \\
\hline $\begin{array}{l}\text { Knowledge of the } \\
\text { Curriculum }\end{array}$ & 8.519 & 12.120 & 16.407 \\
\hline $\begin{array}{l}\text { Knowledge of Classroom } \\
\text { mangement }\end{array}$ & $15.935 *$ & $20.474^{*}$ & $27.364^{* *}$ \\
\hline Adequacy total score & 3.056 & 2.827 & 3.598 \\
\hline
\end{tabular}

Results of the tests of independence (Chi-square) show that knowledgein classroom management is significantly related to the respondents' exposure to electronicmedia. (Chi-square $(8)=15.94$, $\mathrm{p}=0.043$ ); exposure to print media (Chi-square $(10)=20.47, \mathrm{p}=0.025)$ and toschool facilities $\quad($ Chi-square $(10)=27.36, \quad \mathrm{p}=0.002)$. This correlation implies that the role of mass media 
both printed and electronic can never be ignored.Students of the 21st century are characterized as innovative and creative.The use of these media platforms are used advantageously by the learners in enhancing their skills. Tilson and Bekele[71] outline Ethiopia's three decades of experience in using television and radio broadcasts to improve the quality of education in the country,forexample, by supplementing the curriculum and improving access to education. Similarly, Michel and Thomas[72]note the effectiveness of television as an inexpensive, culturally relevant medium for teaching children in Haiti.Bandele[74] noted that the importance of physical facilities cannot be relegated. Facilities like modern laboratories, libraries and classrooms are to be put in place in all our schools. Adesola[75] found out that the level of available resources is indeed a plus to the teachers and goes to show the level of ingenuity and commitment of the teachers toward effective delivery of lesson. Sanoff[86]asserts that school facility assessment can focus on many factors of educational adequacy and excellence. Most obvious is an investigation of thenvironmental factors that impact academic performance and the delivery of the curriculum.Akinfolarin[87]identified facilities as a major factor contributing to academic performance in the schools system. These include classroom furniture, recreational equipment among others. Different studies conducted by Ayodele[88] and Vandiver[89], showed that a positive relationship exists between availability of facilities and student academic performances.

\section{CONCLUSIONS}

Findings on the profile suggests that respondents are of diversed background.Their academic adequacy in general is Fairly Adequate which requires enhancement of their knowledge on curriculum and classroom management as they performed low on these areas. Their place of residence is significantly related to their knowledge on the preparation of instructional materials while exposure to mass media and availability of facilities show relationship to their knowledge on classroom management.

\section{ACKNOWLEDGMENT}

The support of Dr. Gloria Tuzon and Dr. Remely Sanidad from the office of Research and Extension offered a great help in the completion of this study.Dr. Helen Abella,the former Dean of the Graduate School,is sincerely acknowledge for sharing her insights towards the research topic. The cooperation of the respondents and the teachers from the College of Teacher Education,Sta.Maria and Tagudin campus, immensely inspired the researcher.For the statistical treatment of data, gratitude is extended to Prof. Redentor S. Rojas who guided her in analyzing the data.

\section{REFERENCES}

[1] Shulman,L.S.(2004).The Wisdom of Practice:Essays on Teaching,Leraning and Learning to Teach.First Edition.April 20,2004.John Wiley\& Sons Inc,New York,United States

[2] Pawilen G.T.Teaching Profession:Passion and Mission.First Edition.Manila : Rex Book Store, Inc., (C2016

[3] Choy, D., Wong, A., Lim, K., \& Chong, S. (2013). Beginning Teachers' Perceptions of their Pedagogical Knowledge and Skills in Teaching: A Three Year Study. Australian Journal of Teacher Education, 38(5).http://dx.doi.org/10.14221/ajte.201 $3 \mathrm{v} 38 \mathrm{n} 5.6$

[4] Gamage, D., \& Walsh, F. (2003). The significance of professional

development and practice: Towards a better public education system. Teacher Development, 7, 363-37

[5] Gendall, L. (2001). Issues in pre-service mathematics education. The New Zealand Association for Research in Education Conference, Christchurch. Retrievedfromhttp://trove.nla.gov.au/work/ 33424446 
[6] Lingam, G. I. (2010). Teachers equip with new skills. Solomon Star, 4, 12-25

[7] Enginarlar, H. (1996). Praticum in ELT: problemsand prospects. Dil Dergisi, 43, 92-99.

[8] Tuli, F. and File, G. (2009). Practicum experience in teacher education.

EthiopianJournal of Education and

Science.5 (1). 107 - 116.

[9] Williams,J.(2009).beyondthe practicum experience,ELTJournal,63(1),68-77http://d x.doi.org/10.1093/elt/ccn012.

[10] Saricoban,A.(2010).Problemsencountered by student-teachers during their practicum studies. Procedia:Social and Behavioral Sciences,2(2),707-711

[11] Veenman,S.(1984).perceived problems of beginning teachers. review of Educational research,54(2),143-178.http://dx.doi.org/ $10.3102 / 00 \quad 346543054002143$

[12] Durgunoglu, A. Y., \& Hughes, T. (2010). How Prepared are the US Preservice Teachers to Teach English Language Learners? International Journal of Teaching and Learning in Higher Education, 22(1), 32-41.

[13] Ganal, N.\& Andaya,O.J. (2015). Problems of Prospective Teachers of Philippine Normal University, North Luzon Campus During Practice Teaching.Asia Pacific Journal of Research.ISSN: 2320-5504, E-ISSN-2347-4793.

[14] Paghasian, M. (2017); Pre-ServiceEducation and Practice-Teaching

Performances among the Fourth

Year Bachelor of Elementary Education Students of Mindanao State University- Maigo School of Arts and Trades; Journal of Social Sciences (COES\&RJ-JSS), Vol.6, No.2 Special, pp: 114-125.

[15] George, J., Worrell, P., Rampersad, J., and Rampaul, B. ( 2000). Becoming a primary school teacher in Trindad and Tobago (Part 2,Teaching practice experience of Trainees:Discussion paper 21, Multi-Site Teacher Education Research Project). Centre for International Education: University of Sussex Institute of Education.

[16] Darling-Hammond, L., \& J. Baratz-Snowden. (2005). A good teacher in every classroom: Preparing the highly qualified teachers our children deserve. San Francisco, CA: John Wiley \& Sons.

[17] Murphy J. (2003). Task-based learning: the interaction between tasks and learners. ELT Journal, 54 (4), 352-359. Oxford University Press.

[18] Clark,D.\&Cutler,B.Teaching-AnIntroducti on.ISBN 10: 0155865978 / ISBN 13: 9780155865976 Published by Harcourt Brace Jovanovich, San Diego, 1990

[19] Nunan, David. (2009). Second language teaching and learning. Cengage Learning Asia PteLtd. Philippine Edition.

[20] Haigh, M. et.al. (ret., 2015). Practicum's contribution to students' learning to teach. http://www.leeds.ac.uk/educol/documents/ 160597.htm

[21] Gan, Z. (2013). Learning to teach English language in the practicum: what challenges do non-native ESL student teachers face? Australian Journal of Teacher Education. Vol 38, 3. http://ro.ecu.edu.au/cgi/viewcontent.cgi?ar ticle $=1972 \&$ context $=$ ajte

[22] Mansfield, H. (1985). Points, lines, and their representations. For the Learning of Mathematics, 5 (3), 2-6.

[23] McCloskey, M. (1983). Intuitive physics. Scientific American, 248 (4), 122-130. 
[24] Karaman, A. (2017). The place of pedagogical content knowledge in teacher education. Atlas Journal of Science Education, 2(1), 56-60.https://doi.org/10.5147/ajse.2012.00 96

[25] Ball, D. L., \& McDiarmid, G. W. (1990). The Subject Matter Preparation of Teachers. In M. Haberman, J. Sikula \& W.R. Houston (Eds.), Handbook of research on teacher education (pp. 437-449): MacMillan.

[26] Begle, E. G. (1979). Critical variables in mathematics education: Findings from a survey of empirical literature. Washington, DC: Mathematics Association of American and the National Council of Teachers of Mathematics.

[27] Darling-Hammond, L., \& J. Baratz-Snowden. (2005). A good teacher in every classroom:

Preparing the highly qualified teachers our children deserve. San Francisco, CA: John Wiley \& Sons.

[28] Murphy J. (2003). Task-based learning: the interaction between tasks and learners. ELT Journal, 54 (4), 352-359. Oxford University Press.

[29] Clark,D.\&Cutler,B.Teaching-AnIntroducti on.ISBN 10: 0155865978 / ISBN 13: 9780155865976 Published by Harcourt Brace Jovanovich, San Diego, 1990

[30] Nunan, David. (2009). Second language teaching nd learning. Cengage Learning Asia PteLtd. Philippine Edition.

[31] Haigh, M. et.al. (ret., 2015). Practicum's contribution to students' learning to teach.

http://www.leeds.ac.uk/educol/documents /160597.ht m

[32] Gan, Z. (2013). Learning to teach English language in the practicum: what challenges do non-native ESL student teachers face? Australian Journal of Teacher Education. Vol 38, 3. http://ro.ecu.edu.au/cgi/viewcontent.cgi?a rticle $=1972$ \& context=ajte

[33] Mansfield, H. (1985). Points, lines, and their representations. For the Learning of Mathematics, 5 (3), 2-6.

[34] McCloskey, M. (1983). Intuitive physics. Scientific American, 248 (4), 122-130.

[35] Karaman, A. (2017). The place of pedagogical content knowledge in teacher education. Atlas Journal of Science Education, 2(1), 56-60. https://doi.org/10.5147/ajse.2012.0096

[36] Ball, D. L., \& McDiarmid, G. W. (1990). The Subject Matter Preparation of Teachers. In M. Haberman, J. Sikula \& W.R. Houston (Eds.), Handbook of research on teacher education (pp. 437-449): MacMillan.

[37] Zeichner, K. (2006). Reflections of a University-Based Teacher Educator on the Future of College- and University-Based Teacher Education Journal of Teacher Education, 57, 326-340.

[38] Stevens, C., \& Wenner, G. (1996). Elementary Preservice Teachers' Knowledge and Beliefs Regarding Science and Mathematics. School Science and Mathematics, 96(1), 2-9. doi: 10.1111/j.1949-8594.1996.tb10204.x

[39] Abd-El-Khalick, F. (2006). Preservice and experienced biology teachers' global and specific subject matter structures: Implications for conceptions of pedagogical content knowledge. Eurasia Journal of Mathematics, Science and Technology Education, 2(1), 1-29.

[40] Begle, E. G. (1979). Critical variables in mathematics education: Findings from a survey of empirical literature.

Washington, DC: Mathematics Association of American and the National Council of Teachers of Mathematics. 
[41] Stripling,C.,Ricketts, J. C.Roberts,G., Harlin, J.(2008)Preservice

Agricultural Education Teachers' Sense of Teaching Self-Efficacy.Journal of Agricultural Education, v49 n4 p120-135 2008.

[42] Darling-Hammond, L. (2014). Strengthening clinical

[43] preparation: The holy grail of teacher education. Peabody Journal of Education, $\quad 89(4), \quad 547-561$. https://doi.org/10.1080/0161956X.2014.9 39009.

[44] Darling-Hammond, L. (2014). Strengthening clinical preparation: The holy grail of teacher education.

Peabody Journal of Education, 89(4), 547-561.

https://doi.org/10.1080/0161956X.2014.9 39009.

[45] Rosenshine, B., \& Furst, N. (1973). Research on teacher performance criteria. In B.O. Smith (Ed.), Research in teacher education: A symposium. Englewood Cliffs, NJ: Prentice-Hall. [R]

[46] Shinn, Yun Ho, "Teaching strategies, their use and effectiveness as perceived by teachers of agriculture: A national study" (1997). Retrospective Theses and Dissertations. 12244. https://lib.dr.iastate.edu/rtd/12244

[47] Yelon, S. (1996). Powerful Principles of Instruction. New York: Longman

[48] Cunningham,A.(1995)Developing

Marketing Professionals: What can

Business Schools Learn?. Journal of Marketing Education. First Published August 1, 1995 Research Article https://doi.org/10.1177/027347539501700 202

[49] Tomlinson, B. (ed.) 2003. Developing Materials for Language Teaching. London: Continuum Press.

[50] Lampert, M. (1986). Knowing, doing, and teaching multiplication. Cognition and Instruction, 3, 305-342. Lampert, M. (in press).

[51] Samson, P. (2007). Problems and difficulties encountered by student teachers of Philippine Normal University. Philippine Normal University, Isabela Campus, Alicia, Isabela

[52] Basturk, S., \& Donmez, G. (2011). Examining pre-service teachers' pedagogical content knowledge concerning curriculum knowledge. International Online Journal of Educational Sciences, 3(2), 743-775.

[53] Canbazoğlu, S. (2008). Fen Bilgisi Öğretmen Adaylarının Maddenin Tanecikli Yapısı Ünitesine

[54] İlişkin Pedagojik Alan Bilgilerinin

Değerlendirilmesi. Yayınlanmamış Yüksek Lisans

[55] Tezi, Eğitim Bilimleri Enstitüsü Gazi Üniversitesi, Ankara

[56] Biong, C. T. (2014, September). The NationalCompetency-Based Teacher Standards (NCBTS)Among the Students of the College of Education. In The Mindanao Forum 26(1)

[57] B.Corpuz, G. Salandanan .Principle of Teaching. Quezon City,Loriman Publishing Co., Inc, 2007.

[58] Acero, V., Javier, E., Castro, H. (2007).Principles of Teaching 1. Rex Bookstore, Inc. Manila, Philippines

[59] Tyler, R. (2013) Basic principles of curriculum and instruction. In: D. J. Flinders \& S. J. Thornton (eds.), Curriculum Studies Reader (4th ed.), pp. 59-68. New York, NY: RoutledgeFalmer.

[60] Stenhouse L.2012.A process model of curriculum. In Y Reed,J Gultig \& M Adendorff(eds).Curriculum: organizing knowledge for the classroom(3rd ed).Cape Town: Oxford University Press.

[61] Brophy, J. E. (1996). Teaching problem 
students.

New York: Guilford

[62] Rosas, C., \& West, M. (2009) Teachers Beliefs about Classroom Management: Pre-Service and Inservice Teachers'

Belief about Classroom Management. International Journal of Applied Educational Studies, 5, 54-61.

Crookes,G.(2003).A practicum inTESOL:Professional development through teaching practice, New York,NY:Cambridge University Press

[64] Butler, A., \& Monda-Amaya, L. (2016). Preservice Teachers' Perceptions of Challenging Behavior. Teacher

Education and Special Education, 39, 276-292.

[65] https://doi.org/10.1177/088840641665421 2

[66] Ahmad, N. A.,\& Hanifah, N. A. (2015). Special Education Teacher's Level of Knowledge in Dealing with Learning Disabilities Student.

[67] AsiaPacific of Educators and Education, 30, 73-88.

[68] Certo, J. L. (2006). Beginning teacher concerns in an accountability-based testing environment. Journal of Research in Childhood Education, 20(4), 331-349.

Ulla,M.(2016)Pre-service Teacher Training Programs in the Philippines: The Student-teachers Practicum Teaching Experience.EFL JOURNAL Vol. 1 No. 3, 2016 www.efljournal.org e-ISSN: 2502-6054, p-ISSN: 2527-5089 DOI: http://dx.doi.org/10.21462/eflj.v1i3.23.

[70] Raba,A. The Challenge of Classroom Leadership and Management Facing Newly Appointed Teachers. American Journal of Educational Research. 2016; 4(2A):25-29. doi: 10.12691/education-4-2A-4.

[71] Giallo, R., \& Little, E. (2003). Classroom behavior problems: the relationship between preparedness, classroom experiences, and self-efficacy in graduate and student teachers. Australian Journal of Educational \& Developmental Psychology, 3, 21-34.

[72] Maskan, A. K. (2007). Pre-service science and math teachers' difficulties in disruption behavior and class management. International Journal of Educational Reform,16(4),

[73] 336-349. Retrieved online from http://eric.ed.gov/?id=EJ807360

[74] Coskun, A. (2013). Stress in English language teaching practicum: the views of all stakeholders. $H$. U. Journal of Education, 28(3),97110. http://www.efdergi.hacettepe.edu.tr/2013 283.

[75] Yusof, N. et., al. (2014). Student teachers perception towards teaching practicum programme. International Journal for Innovation Education and Research.

Vol.210 , 2014. http://www.ijier.net/assets/student-teache rs-perceptio n-towards-teachingpracticum-program-iji er.net-vol-2 -10-12.pdf

[76] Laruan, MJ. (2006). Problems of student teachers.The Modern Teacher, Vol. LV, No.1.

[77] Ibañez,Maribel C,(2012)"Academic Adequacy of the English Major Students in their Pre-Service Education". A Master's Thesis, University of Northern Philippines.Unpublished Thesis

[78] Ramos,A.(2015)Methods and Teaching Strategies Used by Teacher Education Faculty Members in one State University in the Philippines .Asia Pacific Journal of Multidisciplinary Research Vol. 3 No.5, 36-44

December 2015 Part III P-ISSN 2350-7756 E-ISSN 2350-8442 www.apjmr.com

[79] Capa, Y., \& Cil, N. (2000). Teachers' Attitudes variables. Hacettepe University Journal of Education, 18, 
$69-73$.

[80] Amuda1,B.G. et al(2016)Marital Status and Age as Predictors of Academic Performance of Students of

Colleges of Education in the NortEastern Nigeria. American Journal of Educational Research, 2016, Vol. 4, No. 12, 896-902 Available online at http://pubs.sciepub.com/education/4/12/7 (C) Science and Education Publishing

DOI:10.12691/education-4-12-7

[81] Upcraft, M., \& Pilato, G. (1982). Residence Hall Assistants in College. San Francisco: Jossey-Bass

[82] Mbugua,Z.,Reche, G.Bundi, Triphosa K., Justus N.(2012)Factors contributing to poor performance in Kenya certificate of primary education in public day primary schools in Mwimbi Division, Maara District, Kenya.Retrived July 12, from

http://karuspace.karu.ac.ke/handle/20.500. 12092/170 2Young, B. A. \& Smith., T. $M$ (1997). The social context of education. The Condition of Education, 3, 1-27.

[83] Young, B. A. \& Smith., T. M (1997). The social context of education. The Condition of Education, 3, 1-27.

[84] Draughn,A.(2016 )The impact of psychological birth order on academic achievement and motivation .Walden Dissertations and Doctoral Studies Collection.Walden University

[85] Herrera,N.C.,Zajonc,R.B.,Wieczorkowsk a,G., \& Cichomski,B,(2003).Beliefs About birth rank and their reflections in reality. Journal of Personality \& Social

Psychology,85(1),142-150.DOI:10.1037/ 0022-3514. 85.1.142.68

[86] Leman,K.(2009).The birth order book:Why you are the way you are.Grand Rapids MI:Revell.
[87] Silles,M.A.(2010).The implications of family size and birth order for test scores and behavioral

development.Economics of Education Review

29,795-803.http://dx.doi.org/10.1016/j.ec onedurev.2 010.02.004

[88] Cooper, D. L., Healy, M. A., \& Simpson, J. (1994). Student development through involvement: Specific changes over time. Journal of College Student Development, 35, 98-102.

[89] Tilson, Thomas D. and Demissew Bekele. 2000. Ethiopia: Educational Radio and Television. TechKnowLogia, May/June: 29-31.

[90] Michel, Claudine and R. Murray Thomas. 1985. High-quality, low-cost television for children of developing nations: A Haitian experience. International Journal of Educational Development 5, no. 4: 249-257.

[91] Cynthia, U., \& Megan, T. (2008). The Walls Speak: the interplay of quality facilities, school climate, and student achievement. Journal of Educational Administration, 46 (1), 55-73.

http://dx.doi.org/10.1108/095782308108 49817.

[92] Bandele, S. O. (2003). The Universal Basic Education in Perspective, Need for Formative Evaluation.

Nigeria Journal of Educational Research and Evaluation, 1(4), 54-56.

[93] Adesola, A. A. (2005). Resource Provision and Utilization,

Mathematics Ability and learning Environment as prediction of learning Outcome in Undergraduate Practical Geography. Unpublished Ph.D Thesis, University of Ibadan, Ibadan.

[94] Peters, R. S. (1977). Education and the education of teachers. London: Routledge and Kegan Paul. 
[95] Buchmann, M. (1984). The priority of knowledge and understanding in teaching. In J. Raths and L. Katz (Eds.), Advances in teacher education (Vol. 1, pp. 29-48). Norwood, NJ: Ablex.

[96] Mohamed, Z.; Valcke, M.; de Wever, B. Are they ready to teach? Student teachers' readiness for the job with reference to teacher competence

frameworks. J. Educ. Teach. 2016, 43, 151-170.

[97] Park, M.H.; Dimitrov, D.M.; Patterson, L.G.; Park, D.Y. Early childhood teachers beliefs about readiness for teaching science, technology, engineering, and mathematics. J. Early Child. Res. 2017, 15, 275-291.

[98] Carkhuff, R.R., \& Berenson, D. H. (1981). The skilled teacher: A systems approach to teaching skills. Amherst, MA: Human Resources Development Press.

[99] Anderson, W. R. (1994). Bloom' s Taxonomy: A Forty-Year

Retrospective, Ninety-third Yearbook of the national Society for the Study of Education, Chicago, IL: Longman

[100] CHED CMO No.30,series of 2004-"Guidelines in the

Deployment of Preservice Teachers on Experiential Learning: Field Study and Practice Teaching"

[101] Stoughton, E. H. (2007). "How will I get them to behave?": Pre service teachers reflect on classroom management.

Teaching and Teacher Education, 23(7), 1024-1037.

[102] Bari, S., Yasin, M. H. M., \& Hamzah, M. N. (2012). The Readiness of Special Education Trainees to Teach in Inclusive Program. International Education Studies, 7 , 206-211.https://doi.org/10.5539/ies.v7n1 3p206

[103] Wolfgang \& Glickman. (1996). Solving Discipline Problems: Strategies for
Classroom Teachers. 2nd ed. Boston: Allyn and Bacon.

[104] Sanoff,H.(1996).designing a responsive school: The benefits of a participatory process. School Administraor,53(6).18-22.

[105] Akinfolarin, C. A. (2008). Resource utilization in Vocational and Technical Education in Colleges of Education in South-West Nigeria. Unpublished Ph.D Thesis. University of Ado-Ekiti, Ado-Ekiti.

[106] Ayodele, J. B. (2000). School Size, Class Size and Teacher's Quality as Correlation of Internal Efficiency in Primary School in Ondo State, Nigeria; Unpublished $\mathrm{PhD}$ Thesis, University Ibadan, Ibadan.

[107] Vandiver, B. (2011). The Impact of School facilities on the Learning Environment. (Unpublished Doctoral Dissertation). Capella University 